\title{
槽式集热器集热管外热流分布均匀性的量化评价方法
}

\author{
赵东鹏, 赵力*, 邓帅, 汪大海, 卢雅妮, 郡亚伟 \\ 天津大学机械工程学院, 中低温热能高效利用教育部重点实验室, 天津 300350 \\ *联系人, E-mail: jons@tju.edu.cn
}

2018-05-30 收稿, 2018-09-17 修回, 2018-09-19 接受, 2019-01-11 网络版发表

国家自然科学基金(51776138)资助

\begin{abstract}
摘要定量化描述槽式集热器中集热管外热流分布的均匀程度, 对于集热器的优化设计有着重要的意义. 工程 领域中，现有的均匀性评价指标往往只计及物理量在数值上的分布特征，没有考虑物理量在空间相对位置上的分 布特征. 本文将“均匀度”分解成“均度”和“匀度”两个子指标，从物理量的数值及其相对位置两个层面较为全面地 对热流这一物理量分布的均匀程度展开定量化描述. 通过对特殊分布和 4 种典型的集热器中集热管外热流分布的 均匀性进行量化评价，验证了该指标的合理性以及在管外热流分布均匀性量化分析中的有效性. 同时，新指标具 有严格有界、无量纲等特征，便于在集热器的优化设计中使用，同时在其他工程领域也具有应用潜力.
\end{abstract}

关键词抛物线型槽式集热器, 非均匀热流分布, 量化方法, 均匀度

聚光型太阳能热发电技术被认为是一种具有广 阔应用前景的绿色可再生能源技术，而抛物线型槽 式太阳能集热器由于其成本较低、技术成熟的特点, 成为了目前应用最为广泛的技术之一 ${ }^{[1]}$.

槽式集热器是一种线聚焦式集热器, 在集热管 外会形成非均匀的热流分布, 而管内载热流体的吸 热能力通常是均匀的, 这会使得管壁产生非均匀的 温度分布，造成管壁较大的周向温度梯度和过高的 局部温度 ${ }^{[2,3]}$. 较大的周向温度梯度使得集热管容易 弯曲变形, 偏离聚光器的焦线位置, 降低光学效 率 ${ }^{[4,5]}$. 由于材料属性的差别, 金属材质的集热管和 玻璃材质的外封套管发生不同步变形, 当集热管轴 向变形过大时将触碰玻璃套管，造成玻璃套管破裂， 导致真空失效, 散热损失增大 ${ }^{[6]}$. 此外, 集热管反复 发生热变形容易导致集热管发生热疲劳, 导致集热 管产生永久变形，造成玻璃与金属管的封接失效 ${ }^{[7,8]}$. 过高的局部温度使得吸收涂层性能降低, 载热流体 变性失效, 进而降低集热效率 ${ }^{[9]}$. 因此, 槽式太阳能
集热器中集热管外聚焦热流的非均匀特点, 给集热 器的安全高效运行带来了极大的挑战.

在过去的十多年中，众多学者针对集热管外非 均匀热流的成因、危害和解决方法开展了大量的研 究 ${ }^{[2]}$. 为了从根本上避免集热管外非均匀热流分布所 带来的一系列的弊端, 诸多学者致力于改进型集热 器的研究, 通过改进传统抛物线型槽式集热器的结 构, 提高集热管外热流分布的均匀性. Tsai和 Lin ${ }^{[10]}$, Wang等人 ${ }^{[11]}$ 在该方向做出了卓有成效的研究, 通过 光线追踪法证实设计出的新型集热器相对于传统抛 物线型槽式集热器能够获得更加均匀的管外热流分 布.在相关研究中, 学者们普遍采用图示的方法(图 1)比较集热器在改进前后得到的热流分布，通过图 形来直观地说明改进之后的集热器能够获得更为均 匀的热流分布. 这种图形示意的方法, 对于简单的分 布或均匀性相差较大的情况可以进行快速判断，但 对于一些复杂的分布或者均匀性差别较小的情况无 法实现准确的判断. 因此, 需要一种能够对均匀性进 

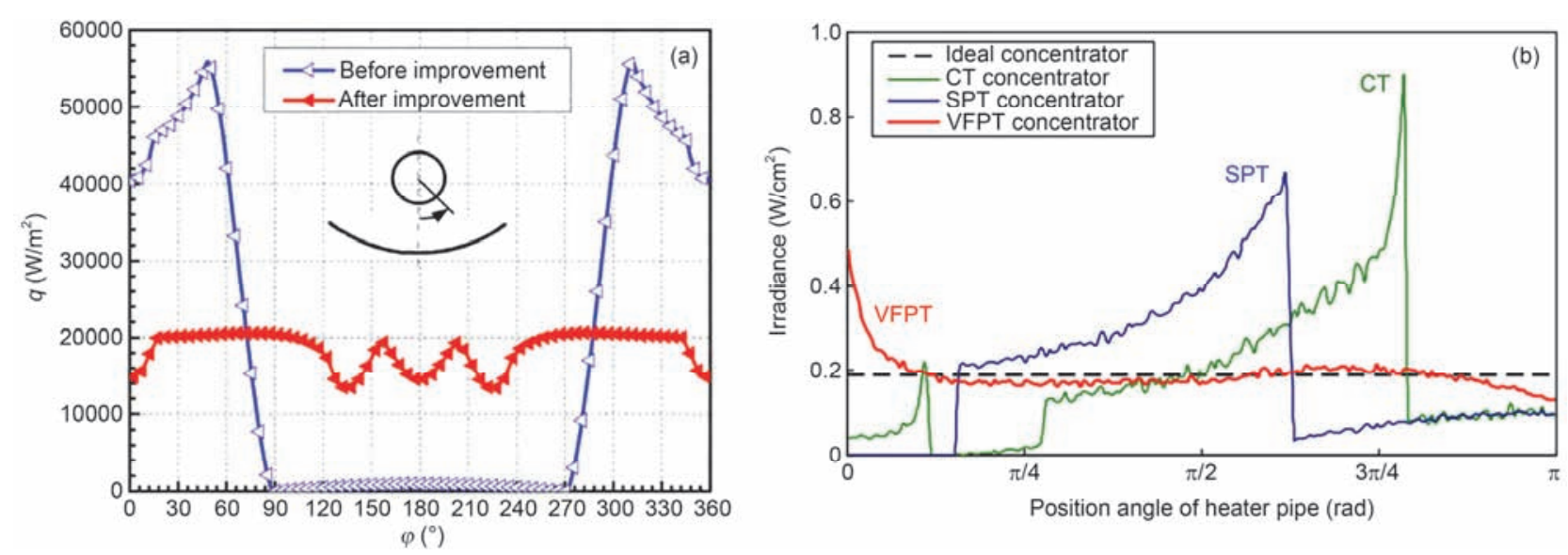

图 1 (网络版彩色)现有研究中普遍采用的图示方法. (a) Wang等人 ${ }^{[11]}$ 的研究; (b) Tsai和Lin ${ }^{[10]}$ 的研究

Figure 1 (Color online) The diagramming method generally used in the existing studies. (a) Wang et al ${ }^{[11]}$; (b) Tsai and Lin ${ }^{[10]}$

行量化描述的方法, 从而可对不同的优化结果在量 化的“边界约束”下进行公平评价, 促进集热器优化 的深人研究.

特别地, 在其他工程领域中, 物理量在空间上的 非均匀分布也是一类普遍存在的现象, 诸如食品冷 藏车中温度的非均匀分布 ${ }^{[12]}$ 、中央空调系统的送风 道中速度的非均匀分布 ${ }^{[13]}$ 、农业喷灌系统中水量的 非均匀分布 ${ }^{[14]}$ 等. 在这类问题中, 物理量在空间上 分布的均匀性对设备/系统的工作性能有直接的影响. 为了改善这些设备/系统的工作性能, 公平地衡量相 关的优化设计的改进效果, 首要的问题也是对物理 量的均匀性进行定量化描述, 服务后续优化分析的 展开.

因此, 针对集热管外热流分布均匀性的量化描 述是非常有必要的, 也是现阶段该领域中的研究有 所忽视的. 本文将在考察现有研究中的关于均匀性 量化指标的基础上, 提出针对槽式太阳能集热器中 集热管外热流分布均匀性的量化指标, 并对 4 种典型 槽式太阳能集热器管外热流分布的均匀性进行了量 化评价.

\section{1 均匀性/非均匀性量化指标的研究现状}

在工程实践中, 均匀性/非均匀性评价方法是一 个先采样, 然后分析整理数据的过程, 是一个典型的 统计调查实验. 因此, 研究者往往采用统计学上常用 的统计量或者其变化形式作为描述物理量分布均匀 性/非均匀性的指标. 在许多领域都涉及到均匀性/非 均匀性量化研究, 本文将对这类研究进行简要的总
结, 尝试从中总结出均匀性量化指标的一般性特征.

温度是能源、环境等领域经常涉及到的物理量, 其分布的均匀性对许多工程问题有重大影响, 故成 为学者对于均匀/非均匀性研究的主要考察参数. Cheng等人 ${ }^{[15]}$ 在研究喷射冷却表面温度非均匀分布 形成机理时用表面温度的极差来定义温度的非均匀 程度. 张哲等人 ${ }^{[12]}$ 在讨论冷藏车温度场不均匀性对 蔬菜保鲜效果影响的研究中引人绝对不均匀度 $($ 表 1 中式(2))的来描述温度分布的非均匀程度．杨昆等 人 $^{[16]}$ 在研究柴油机排气温度分布时采用相对偏差来 描述排气温度的非均匀程度. Xie等人 ${ }^{[17]}$ 研究辐射冷 却板的温度分布时采用类似标准偏差的指标来描述 温度的非均匀程度. Han等人 ${ }^{[18]}$ 在研究铜管在退火过 程中的温度分布时采用表1中式(5)来描述温度场的 非均匀程度.

速度是工程各领域普遍涉及到的物理量, 因此, 也有许多关于速度场分布均匀性的量化研究. Jeong 和 $\mathrm{Kim}^{[19]}$ 在优化汽车尾气催化系统采用表1式(6)来衡 量速度分布的均匀程度, 该指标无量纲、有界的特性 使其在后续的研究中被广泛的采用. 陶红歌等人 ${ }^{[13]}$ 在研究地铁车辆风道送风系统是提出了基于面积加 权平均速度和质量加权平均速度的流体流动均匀性 指标(表1中式(7)).

在农业灌溉领域，水量分布的均匀性是衡量喷 灌设备性能的主要指标, 因此有大量针对水量分布 均匀/非均匀性评价指标的研究. 基于平均离差的克 里斯琴森(Christiansen)均匀系数(表1中式(8))是目前 农业喷灌领域最常采用的度量水量分布均匀程度的 


\section{表 1 工程领域中常用的均匀性/非均匀性指标总结a)}

Table 1 Summary of the common uniformity/non-uniformity indexes in engineering ${ }^{\text {a) }}$

\begin{tabular}{|c|c|c|c|c|c|c|}
\hline 物理量 & $\begin{array}{l}\text { 参考 } \\
\text { 文献 }\end{array}$ & 指标计算方法 & & 无量纲 & 有界性 & 应用场景 \\
\hline \multirow{5}{*}{ 温度 } & {$[15]$} & 均匀指数 $=\max \left(x_{i}\right)-\min \left(x_{i}\right)$ & (1) & $x$ & $x$ & 评价喷射冷却时壁面温度分布的均匀程度 \\
\hline & {$[12]$} & 非均匀指数 $=\sum_{i=1}^{n} \frac{\left|x_{i}-\bar{x}\right|}{\bar{x}}$ & $(2)$ & 无量纲 & $x$ & 评价冷藏车中温度分布的非均匀程度 \\
\hline & {$[16]$} & 非均匀指数 $=\frac{\left|x_{i}-\bar{x}\right|}{\bar{x}}$ & $(3)$ & 无量纲 & $x$ & 评价柴油发动机排气温度分布的非均匀程度 \\
\hline & {$[17]$} & 非均匀指数 $=\frac{\sigma}{\bar{x}}=\frac{\sqrt{\sum_{i=1}^{n}\left(x_{i}-\bar{x}\right)^{2}}}{n} / \bar{x}$ & $(4)$ & 无量纲 & $x$ & 评价辐射冷却板表面温度分布的非均匀程度 \\
\hline & {$[18]$} & 均匀指数 $=\frac{\max \left(x_{i}\right)-\min \left(x_{i}\right)}{\left(\max \left(x_{i}\right)+\min \left(x_{i}\right)\right) / 2}$ & $(5)$ & 无量纲 & {$[0,1]$} & 评价铜管退火时壁面温度分布的均匀程度 \\
\hline \multirow[t]{2}{*}{ 速度 } & {$[19]$} & 均匀性指数 $=1-\frac{1}{2 n} \sum_{i=1}^{n} \frac{\sqrt{\left(x_{i}-\bar{x}\right)^{2}}}{\bar{x}}$ & $(6)$ & 无量纲 & $(0,1]$ & 评价尾气催化器中截面速度分布的均匀程度 \\
\hline & {$[13]$} & 均匀性指数 $=\frac{\bar{x}_{\mathrm{A}}}{\bar{x}_{\mathrm{M}}}$ & (7) & 无量纲 & $x$ & 评价地铁送风道截面速度分布的均匀程度 \\
\hline \multirow{2}{*}{ 质量 } & {$[20]$} & 非均匀指数 $=1-\frac{\sum_{i=1}\left|x_{i}-\bar{x}\right|}{\bar{x}} / \bar{x}$ & $(8)$ & 无量纲 & $(0,1]$ & 评价农田喷灌水量分布的非均匀程度 \\
\hline & {$[22]$} & 均匀指数 $=\frac{\bar{x}-\sum_{i=1}^{n}\left(x_{i}-\bar{x}\right)^{2}}{\bar{x}}$ & $(9)$ & $x$ & $x$ & 评价干燥器中物品脱水量分布的均匀程度 \\
\hline 电场强度 & {$[21]$} & 非均匀指数 $=\frac{\max \left(x_{i}\right)}{\bar{x}}$ & $(10)$ & 无量纲 & $x$ & 评价电场中电场强度分布的非均匀程度 \\
\hline 辐照强度 & {$[23]$} & 非均匀指数 $=\frac{\max \left(x_{i}\right)-\min \left(x_{i}\right)}{\max \left(x_{i}\right)+\min \left(x_{i}\right)}$ & (11) & 无量纲 & $x$ & 评价太阳辐照模拟器中辐照强度分布的非均匀程度 \\
\hline
\end{tabular}

a) $x_{i}$ 为第 $i$ 个测点处物理量的值; $n$ 为测点的总数目; $\bar{x}$ 为所有测量值的平均值; $\bar{x}_{\mathrm{A}}$ 为面积加权平均值; $\bar{x}_{\mathrm{M}}$ 为质量加权平均值; $\max \left(x_{i}\right)$ 表示取所有测量值中的最大值; $\min \left(x_{i}\right)$ 表示取所有测量值中的最小值. “ $\times ”$ 表示不满足相关性质

方法 ${ }^{[20]}$. 此外, 一些研究中也采用变异系数来衡量 水量分布的均匀程度 ${ }^{[14]}$.

在其他工程问题上, 也有许多衡量物理量分布 均匀性/非均匀性的评价指标. 张波等人 ${ }^{[21]}$ 在研究电 场强度的分布时, 采用最大值和平均值的比值作为 电场强度分布非均匀程度的衡量指标. Song等人 ${ }^{[22]}$ 采用表 1 中式(9)的方法来衡量干燥器中物品干燥程 度的非均匀性. 张国玉等人 ${ }^{[23]}$ 在针对太阳能模拟器 的研究中采用表1中式(11)来计算辐照强度分布的非 均匀程度.

通过比较表1中工程领域用到的评价物理量分布 均匀性/非均匀性的各种指标, 可以看出现有的指标 存在以下 3 个问题: (1) 部分指标没有确定的取值范 围, 难以对不同的分布形式进行比较; (2) 部分指标 带有量纲, 不能对不同的物理量分布进行比较; (3)
由于均匀性/非均匀性的评价过程是通常是一个统计 调查实验, 受方法影响, 评价中往往只考虑测点数据 的数值信息, 仅反映数值的平均值或者离散 $/$ 聚集程 度, 但忽略了测点数据的位置信息, 这使得其对物理 量分布均匀性的描述存在片面性. 这 3 个问题使得这 些评价指标的通用性不强, 实际操作中可比性不高, 也无法全面描述分布的均匀性, 使其难以给相关的 设计和优化提供有效的指导. 因此，一种可靠的均匀 性量化指标不仅要满足有界、无量纲的基本条件, 还 需要综合考虑到测点数据的数值信息和位置信息, 才能在全面描述物理量分布均匀性的基础对工程优 化提供有效的指导.

\section{2 新均匀度指标简介}

基于上节中均匀性指标需要综合考虑测点数据 
的数值信息和位置信息的讨论, 本文将 “均匀度”的 概念分解为两个层面. 第一个层面是数据的数值分 布层面, 即“均度”的概念, 其反映无维度数据呈现出 的向平均值聚拢的程度; 第二个层面是数据的空间 位置分布层面, 即“匀度”的概念, 其反映空间内各区 域的数据在数值上的接近程度. “均匀度”同时包含 “均度”和 “匀度”, 是这两个基础指标的组合. 接下 来, 将分别介绍“均度”和“匀度”的计算方法.

“均度”反映无维度数据呈现出的向平均值聚拢 的程度, 表1列举的现有指标中有部分指标可以作为 “均度”的计算方法. 考虑到该指标应该拥有无量纲、 有界的特点, Weltens等人 ${ }^{[24]}$ 提出的指标具备上述特 征, 并在描述速度分布均匀程度的研究中得到了广 泛的应用 ${ }^{[19,25]}$. 因此, “均度”的计算方法借鉴该指标 的计算方法, 表达式如下:

$$
U_{1}=1-\frac{1}{2 n} \sum_{i=1}^{n} \frac{\sqrt{\left(x_{i}-\bar{x}\right)^{2}}}{\bar{x}},
$$

式中, $x_{i}$ 表示空间上按照一定规律布置的任意测点的 值; $\bar{x}$ 表示所有测点的平均值. $U_{1}$ 的取值范围为 $[0,1]$, $U_{1}$ 越大表示数据的“均度”越好. 当 $U_{1}$ 取 1 时, 表示所有 测点的值都相等; 当 $U_{1}$ 取 0 时, 表示只有一个测点有值.

“匀度”反映空间内各区域的数据在数值上的接 近程度, 其与数据在空间上的分布有紧密的联系. 尚 卫平 ${ }^{[26]}$ 在研究收人差异程度的指标时, 借鉴信息熵 的概念设计出了 “余期望系数” 的指标, 研究表明该 指标能够较好地反映不同数据之间的差异程度. 本 研究借鉴“余期望系数”的构造思想, 提出了如下所 述的“均度”计算方法.

(1) 对计算 “均度”所用到的测点进行空间区域 划分, 每个区域内应至少包括2个测点(图2). 划分好 的区域依次标记为: I, II, III, IV, $\mathrm{V} \cdots N$, 则每 个区域内的测点数量为

$$
n_{q}=\frac{n}{N} \text {. }
$$

(2) 计算该区域内的平均值:

$$
\bar{x}_{q}=\frac{\sum_{i=1}^{n_{q}} x_{\mathrm{I}, i}}{n_{q}} \quad(q=\mathrm{I}, \mathrm{II}, \mathrm{III}, \mathrm{I}, \mathrm{V} \cdots N) .
$$

(3) 计算区域平均值的最大值:

$$
\bar{X}_{\text {max }}=\max \left(\bar{x}_{q}\right) .
$$

(4) “匀度”指标可以按下式计算:

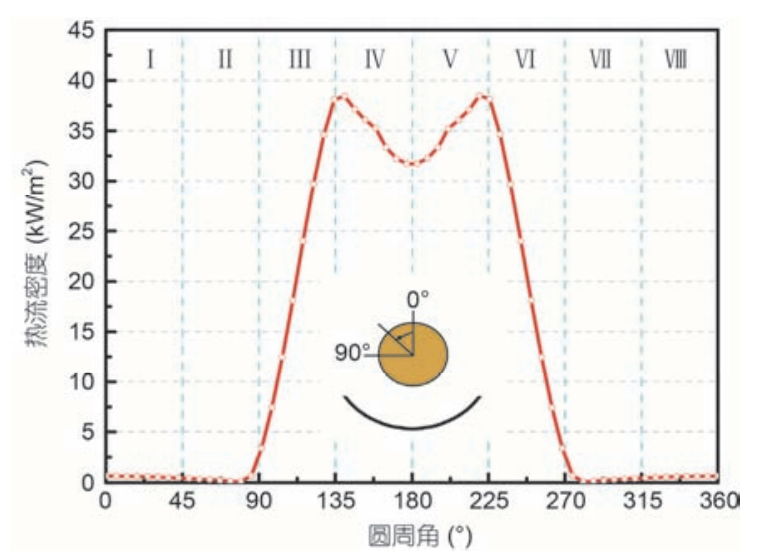

图 2 (网络版彩色)“匀度” $\left(U_{2}\right)$ 的计算方法示意图

Figure 2 (Color online) The diagram of $U_{2}$ calculation method

$$
U_{2}=\frac{\sum p_{q} \log \left(1 / p_{q}\right)}{\log N} .
$$

式中 $p_{q}=\bar{x}_{q} /\left(X_{\text {max }} \cdot N\right)$ 代表区域 $q$ 中的值在可能存在 的最大总值中的占比. 当 $U_{2}$ 取得最大值 1 时, $p_{\mathrm{I}}=p_{\mathrm{II}}=\ldots=p_{N}=1 / N$, 表示各区域中的值均等; 当 $U_{2}$ 越接近最小值 0 时, 表示各区域的值分布越不均匀. 区域的大小对“均度”指标的计算结果有一定的影响, 在实际应用需要通过试算确定适宜的计算区域大小.

“均匀度”指标既包含“均度”, 又包含“匀度”, 是 两个子指标的综合体现. 在保证“均匀度”指标有界、 无量纲的前提下, 需要选择合适的方法将 “均度”和 “匀度”进行组合. 在数学逻辑中, 加法隐含“或”的含 义, 而乘法隐含“且”的含义, 因此“均匀度”宜表示为 “均度”和“匀度”的乘积, 计算方法式所示:

$$
U=U_{1} \times U_{2} \text {. }
$$

从新指标的构造过程可以看出, 新指标具有以 下3个特点:

(1) 新指标是无量纲的, 可以用以描述不同类型 的物理量分布;

（2）新指标是严格有界的，其数值范围为 $[0,1]$;

(3) 新指标的两个子指标(“均度”和“匀度”)在极 限情况下是一致的. 当各个位置的值都相等时, “均 度”和“匀度”均为 1 ; 当只有一个位置有值时, “均度” 和“匀度”均趋于 0 .

\section{3 案例分析}

\section{1 新指标和现有指标的应用比较}

图3列举出3组特殊的分布案例, 每组数据的平 


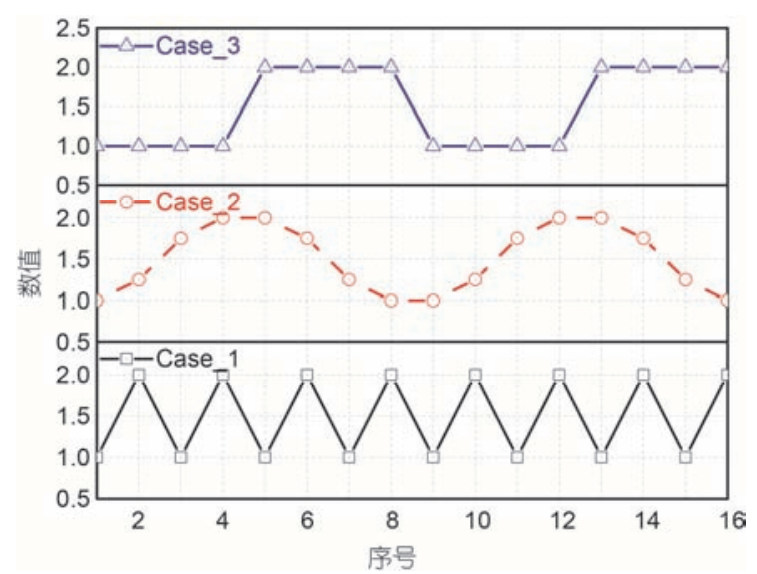

图 3 (网络版彩色) 3 种特殊分布案例的示意图

Figure 3 (Color online) The diagram of the different distributions

均值均为 1.5. 首先利用新指标对其均匀性进行评价, “匀度”的计算区域设定为 2 , 计算结果如图 4 所示. 从 图4中可以看出: Case1和Case3的 “均度”相等, 因为 这两组分布 1 和 2 的个数相等, 但排列顺序不同; Case 1 的 “匀度”为 1 , 因为在计算区域内, 其平均值都 为 1.5. 总体来说, Case1的均匀程度最高, Case3的均 匀程度最低.

为了比较新指标和现有指标在均匀性评价效果 上的差别, 利用新指标和表 1 中的部分指标对上述 3 种特殊分布案例进行均匀性评价, 计算结果如图 5所 示. 从图 5 中可以看出, 新指标对 3 种分布有较好的区 分性. 指标式(5)对3种分布的计算结果一样, 无法达 到区分目的. 指标式(6)和式(8)对Case1和Case2两种 分布无法区分.

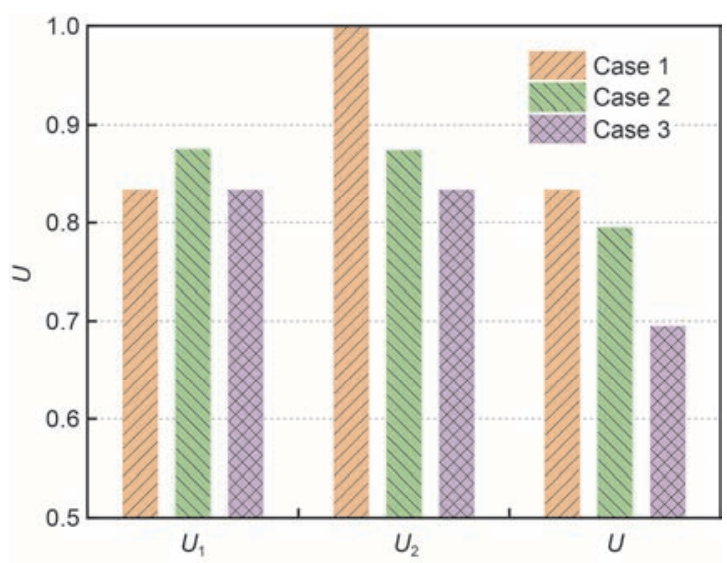

图 4 (网络版彩色)新指标对特殊分布案例的均匀性评价结果

Figure 4 (Color online) Results of uniformity evaluation using the new index

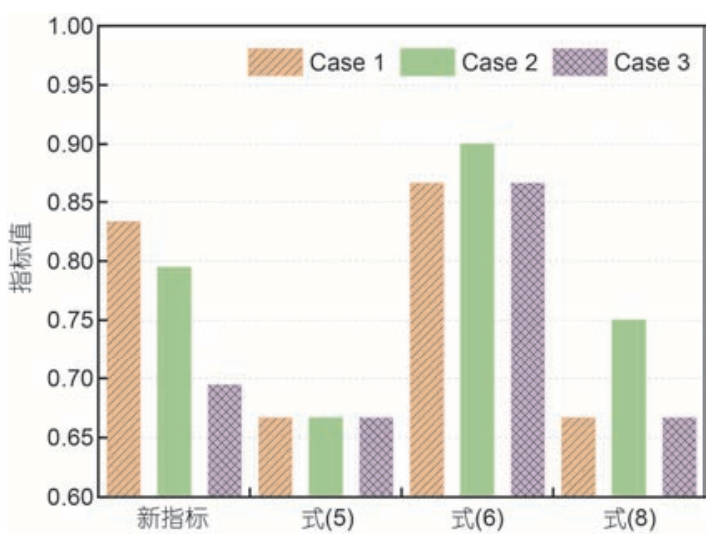

图 5 (网络版彩色)新指标和既有指标对特殊分布案例的均匀性评价 结果

Figure 5 (Color online) Results of uniformity evaluation using the different indexes

从上述分析中可以看出, 新指标对于特殊分布 有较强的甄别能力. 而现有的指标无法对 “均度”相 等的分布进行区分，这也印证现有评价指标的局限 性，同时也佐证了将“均匀度”分解成“均度”和“匀度” 两个子指标的必要性. 从“均度”和“匀度”两个层面评 价分布的均匀性, 扩展了对物理量空间均匀分布的 理解维度, 对于全面评价物理量分布的均匀性有重 要意义.

\section{2 不同集热器集热管外热流分布均匀性的量化 评价及比较}

本节选取了 4 种较为典型的槽式集热器形式, 分 别是 Tsai和 Lin ${ }^{[10]}$ 提出的 “变焦距” 抛物面槽式集热 器(variable focus parabolic trough, VFPT), 圆柱槽式 集热器(cylindrical trough, CT), 传统抛物槽式集热器 (standard parabolic trough, SPT) 以及Wang等人 ${ }^{[11]}$ 提 出的带有二次反射镜的改进型集热器(parabolic trough with homogenizing reflector, PT-HR). 并绘制了4种集 热器的集热管外热流的分布曲线, 如图6所示. 从图6 中可以直观地看出, 相比于 CT 和 SPT型集热器, VFPT型集热器和PT-HR型集热器获得的管外热流分 布要更加均匀. 但是无法准确判断出VFPT型集热器 和PT-HR型集热器的相对优劣, 以及CT和SPT型集 热器的相对优劣. 接下来, 将采用上节提到的新均匀 度指标对上述4种集热器获得的热流分布进行均匀性 量化计算.

由于“匀度”的计算结果比较依赖于空间的区域 划分方式，为了得到适宜的计算区域划分方式，本节 


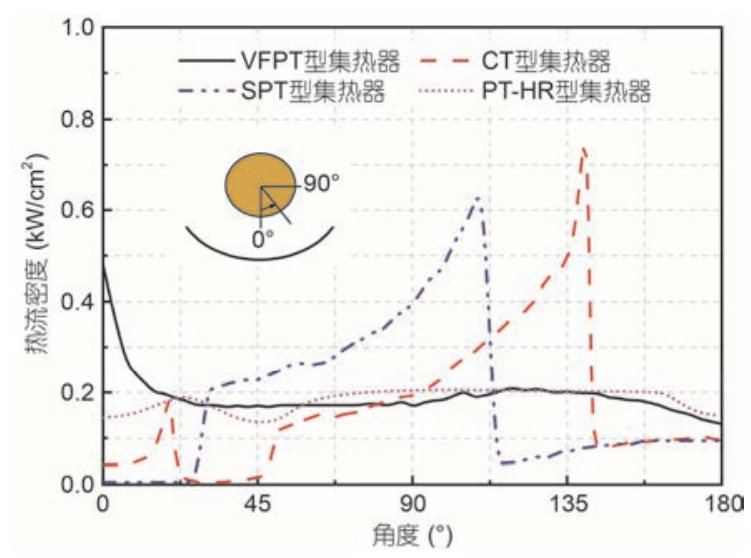

图 6 (网络版彩色)不同结构的集热器的集热管外热流分布 ${ }^{[10,11]}$

Figure 6 (Color online) The different heat flux distributions in different types PTC ${ }^{[10,11]}$

首先计算不同区域数下的“匀度”指标, 结果如图7所 示. 从图7中可以看出, 4种分布的“匀度”指标相对关 系为: PT-HR $>V F P T>C T$ 和SPT, CT和SPT型集热器获 得热流分布在 “匀度”指标上较为接近. 4 种热流分布 形式的 “匀度”指标都随着区域数的增多而减小, 最 后逐渐平缓, 这是由于区域越小, 极大值影响越大, 各区域的均值接近程度越差. VFPT型、CT型和SPT 型集热器的“匀度”指标下降很快, 这是由于这3种集 热器获得的热流分布都存在尖锐的突变. 将“匀度” 值趋于平缓的区域数选定为适宜的计算区域大小, 在本例中计算区域大小为 $7.2^{\circ}$ 的圆周角对应的区域.

图8展示了不同结构集热器的集热管外热流分布 的均匀性计算结果, 可以看出4种分布的整体均匀性 相对关系为: PT-HR $>$ VFPT $>$ SPT $>C T$; “均度”相对关

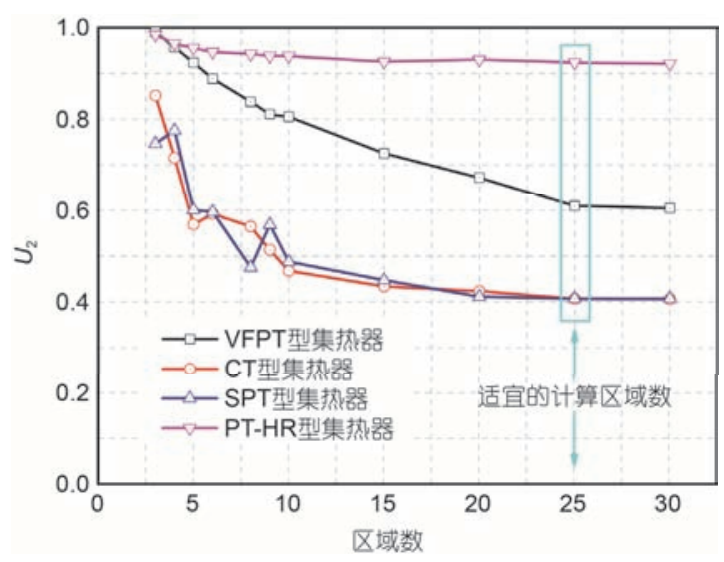

图 7 (网络版彩色)“匀度” $\left(U_{2}\right)$ 指标计算区域大小的独立性检验

Figure 7 (Color online) Independence test for the size of calculation zone

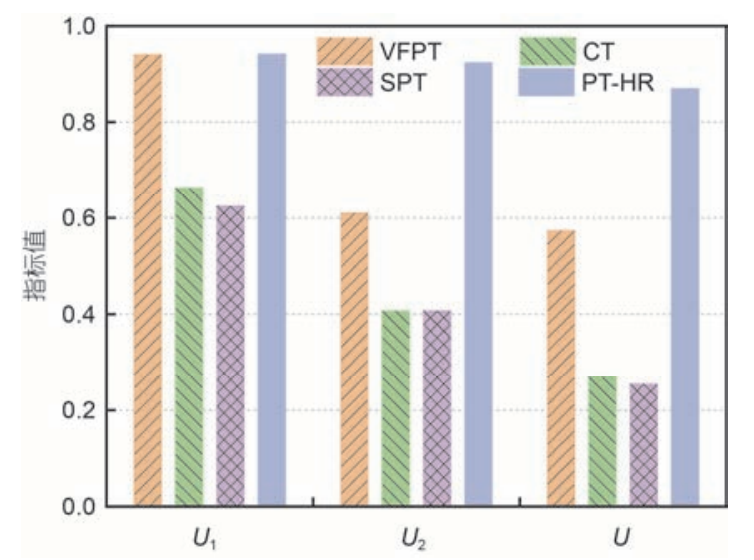

图 8 (网络版彩色)不同结构集热器的集热管外热流分布的均匀性计 算结果

Figure 8 (Color online) Results of uniformity evaluation of heat flux distributions in PTCs

系为: $\mathrm{PT}-\mathrm{HR} \approx \mathrm{VFPT}>\mathrm{SPT}>\mathrm{CT}$; “匀度”相对关系为: $\mathrm{PT}-\mathrm{HR}>\mathrm{VFPT}>\mathrm{SPT} \approx \mathrm{CT}$. 利用新均匀度指标评价的 结果与 Tsai和 $\mathrm{Lin}^{[10]}$, Wang等人 ${ }^{[11]}$ 在各自研究中得到 的结果一致(文献[10]中图9和10, 文献[11]中图 13和 14). 此外, 从图8中也可以看出，单一使用“均度”指 标和“匀度”指标有可能出现无法区分的情况(PT-HR 和VFPT的“均度”近似相等, CT和SPT的“匀度”近似 相等), 这也从实例的角度验证了将“均匀度”分解成 “均度”和“匀度”两个子指标的必要性.

\section{4 结论}

衡量槽式集热器中集热管外热流分布的均匀程 度, 对于集热器的优化设计有着重要的意义. 通过对 工程实践中现有的均匀度指标进行总结和分析, 发 现现有指标存在 3 个问题：(1) 部分指标取值范围不 定; (2) 部分指标带有量纲; (3) 现有指标普遍只考虑 了测点数据的数值信息, 而忽略了位置信息.

本文将“均匀度”分解为涵盖数值信息的“均度” 和涵盖位置信息的“均度”这两个子指标的乘积，其 中“均度”反映无维度数据呈现出的向平均值聚拢的 程度, “匀度”反映不同空间部分的数据在数值上的接 近程度. 同时, 该均匀度指标还具有严格有界(取值 范围为 $[0,1])$ 、无量纲的特性.

利用新指标对 4 种集热器的集热管外热流分布进 行均匀性评价, 结果表明该指标能较好地对集热管外 热流分布的均匀性进行量化. 相比与现有的指标, 新 指标也能较好地区分一些特殊分布在均匀性上的差别. 
综上所述，该均匀度指标及配适的量化计算方 法，具有明确的物理意义和清晰的计算流程，能够较
为全面地评价物理量分布的均匀程度，具有很强的 实用价值.

\section{参考文献}

1 Lovegrove K, Stein W. Concentrating Solar Power Technology: Principles, Developments and Applications. Cambridge (UK): Woodhead Publishing Limited, 2012

2 He Y L, Wang K, Du B C, et al. Non-uniform characteristics of solar flux distribution in the concentrating solar power systems and its corresponding solutions: A review (in Chinese). Chin Sci Bull, 2016, 61: 3208-3237 [何雅玲，王坤，杜保存，等. 聚光型太阳能热发 电系统非均匀辐射能流特性及解决方法的研究进展. 科学通报, 2016, 61: 3208-3237]

3 Wang Y, Liu Q, Jing L, et al. Performance analysis of a parabolic trough solar collector with non-uniform solar flux conditions. Int J Heat Mass Transfer, 2015, 82: 236-249

4 Han L. Study on heat transfer characteristics for parabolic through solar collector (in Chinese). Master Dissertation. Beijing: North China Electric Power University, 2017 [韩露. 槽式太阳能集热器热性能研究. 硕士学位论文. 北京: 华北电力大学, 2017]

5 Li H X. Thermal characteristics of parabolic trough solar absorber with non-uniform heat flux (in Chinese). Master Dissertation. Chongqing: Chongqing University, 2013 [李洪香. 非均匀热流分布下槽式太阳能吸热管的热特性. 硕士学位论文. 重庆: 重庆大学, 2013]

6 Wu J J, Hou H J, Yang Y P. Thermal stress analysis of parabolic through solar receivers (in Chinese). J Eng Thermophys, 2015, 2 249-253 [吴俊杰, 侯宏娟, 杨勇平. 槽式太阳集热管热应力分析. 工程热物理学报, 2015, 2: 249-253]

7 Lei D, Wang Z, Li J, et al. Experimental study of glass to metal seals for parabolic trough receivers. Renew Energy, 2012, 48: 85-91

8 Wu Z, Lei D, Yuan G, et al. Structural reliability analysis of parabolic trough receivers. Appl Energy, 2014, 123: 232-241

9 Moens L, Blake D M. Mechanism of hydrogen formation in solar parabolic trough receivers. J Sol Energy Eng, 2010, 132: 5154

10 Tsai C, Lin P D. Optimized variable-focus-parabolic-trough reflector for solar thermal concentrator system. Sol Energy, 2012, 86: 1164-1172

11 Wang K, He Y, Cheng Z. A design method and numerical study for a new type parabolic trough solar collector with uniform solar flux distribution. Sci China Tech Sci, 2014, 57: 531-540

12 Zhang Z, Li L M, Tian J J, et al. Effects of refrigerated truck temperature field uniformity on preservation of vegetables (in Chinese). Trans Chin Soc Agric Eng, 2014, 15: 309-316 [张哲, 李立民, 田津津, 等. 冷藏车温度场不均匀度对蔬菜保鲜效果的影响. 农业工 程学报, 2014, 15: 309-316]

13 Tao H G, Chen H X, Xie J L, et al. Flow uniformity index based on area-weighted and mass-weighted average velocity (in Chinese). J Chem Ind Eng (China), 2010, (S2): 116-120 [陶红歌，陈焕新，谢军龙，等. 基于面积加权平均速度和质量加权平均速度的流体流 动均匀性指标探讨. 化工学报, 2010, (S2): 116-120]

14 Han Q B, Sun H, Wu F, et al. Research status and development trends on sprinkler uniformity coefficient (in Chinese). Water Sav Irrig, 2011, 12: 74-78 [韩启彪, 孙浩, 仵峰, 等. 喷灌均匀系数研究现状及发展趋势. 节水灌溉, 2011, 12: 74-78]

15 Cheng W L, Han F Y, Liu Q N, et al. Theoretical investigation on the mechanism of surface temperature non-uniformity formation in spray cooling. Int J Heat Mass Transfer, 2012, 55: 5357-5366

16 Yang K, Yang L, Su G, et al. Diagnosis of exhaust temperature non-uniformity of diesel engine based on infrared temperature measurement (in Chinese). Infrared Technol, 2014, (3): 244-248 [杨昆, 杨立，苏高，等. 基于红外测温的柴油机排气温度不均匀度诊断. 红 外技术, 2014, (3): 244-248]

17 Xie D, Wang Y, Wang H, et al. Numerical analysis of temperature non-uniformity and cooling capacity for capillary ceiling radiant cooling panel. Renew Energy, 2016, 87: 1154-1161

18 Han Y, Yu E, Han Z. Study on temperature distribution non-uniformity of inner grooved copper tubes during pit furnace annealing. Int J Heat Mass Transfer, 2017, 104: 749-758

19 Jeong S, Kim W. A study on the optimal monolith combination for improving flow uniformity and warm-up performance of an autocatalyst. Chem Eng Process, 2003, 42: 879-895

20 Makki E K, Ali O O, Mohamed A E. Evaluation of uniformity coefficient and water distribution efficiency of some impact sprinklers in Shambat, Sudan. UKJ Agric Sci, 2011, 19: 161-177

21 Zhang B, Chu J Y, Xu X H, et al. Calculation of field non-uniform coeffcient by PDE Tool Box (in Chinese). High Volt Eng, 2005, (6): 1-2 [张波, 储金宇, 许小红. 利用 PDEtool box 计算电场不均匀系数. 高电压技术, 2005, (6): 1-2]

22 Song C, Wang Y, Wang S, et al. Non-uniformity investigation in a combined thermal and microwave drying of silica gel. Appl Therm Eng, 2016, 98: 872-879

23 Zhang G Y, Lü W H, He X L, et al. Analysis on irradiation uniformity of sun simulator (in Chinese). Chin J Opt Appl Opt, 2009, (1): 41-45 [张国玉，吕文华，贺晓雷，等. 太阳模拟器辐照均匀性分析. 中国光学与应用光学, 2009, (1): 41-45]

24 Weltens H, Bressler H, Terres F, et al. Optimisation of catalytic converter gas flow distribution by CFD prediction. SAE Technical Paper, 1993,930780

25 Li T, Jin S P, Huang S Y, et al. Evaluation indices of flow velocity distribution uniformity: Comparison and application (in Chinese). Therm Power Gen, 2013, 11: 60-63 [李坦, 靳世平, 黄素逸, 等. 流场速度分布均匀性评价指标比较与应用研究. 热力发电, 2013, 11: 60-63]

26 Shang W P. A new indicator to measure the gap of income distribution residual-Expectation coefficient (in Chinese). Stat Res, 2004, (1): 35-37 [尚卫平. 一种反映收人差异程度的新指标——余期望系数. 统计研究, 2004, (1): 35-37] 


\title{
A quantitative evaluation method for uniformity of heat flux distribution in the parabolic trough collector
}

\author{
Dongpeng Zhao, Li Zhao", Shuai Deng, Dahai Wang, Yani Lu \& Yawei Shao \\ Key Laboratory of Efficient Utilization of Low and Medium Grade Energy, Ministry of Education of China, School of Mechanical Engineering, \\ Tianjin University, Tianjin 300350, China \\ * Corresponding author, E-mail: jons@tju.edu.cn
}

The parabolic trough collector (PTC) is one of the most mature technologies to harvest solar energy for heat applications. However, the non-uniform heat flux distribution on the outer surface of absorber tube can lead to a high local temperature and a large temperature gradient on the tube wall, thus resulting into many issues, such as the degradation of the selective coating, the vacuum loss, the deformation of the absorber tube, and even the breakage of the glass envelope. These issues pose great challenges for the safety and high-efficiency operation of PTC systems. The corresponding effective solution is to increase the uniformity of the heat flux distribution on the absorber tube. Based on this purpose, how to quantify the uniformity of heat flux distribution is of great significance for the design of the parabolic trough collector. In this work, the existing uniformity indexes in engineering are summarized and compared. It is found that there are three problems in the related studies: (1) Some indexes are unbounded, which makes it difficult to compare uniformity of different distribution types; (2) some indexes are dimensioned, and it's difficult to compare uniformity of different physical quantities distribution; (3) for most of the existing indexes, only the value of physical quantity is considered, while the spatial distribution characteristic of physical quantity is ignored. This phenomenon makes the description of uniformity incomprehensive. In view of this, a new uniformity index is proposed to consider both the value and spatial position of physical quantity by decoupling "uniformity index" into "uniformity index of value" and "uniformity index of spatial position". The "uniformity index of value" is to quantify the dispersion degree of a set of data values from the average, and the "uniformity index of spatial position" is to quantify the amount of dispersion of data values in different spatial zones. The effectiveness of the proposed uniformity index is verified by evaluating the uniformity of three different distributions. Compared with existing uniformity indexes, the proposed index has a better ability to distinguish the uniformity of the distribution. Thereafter, the proposed uniformity index is employed to evaluate the uniformity of heat flux distribution in four typical types of PTC. The obtained results show that the proposed uniformity index can quickly and accurately evaluate the uniformity of heat flux distributions in PTC. Furthermore, due to the characteristics of strict boundedness and dimensionless, the proposed index can be easily applied as the guidance of PTC design and optimization.

parabolic trough collector, non-uniform heat flux distribution, quantitative evaluation method, uniformity index doi: 10.1360/N972018-00524 